\title{
Credit rationing and crowding out during the industrial revolution: evidence from Hoare's Bank, 1702-1862
}

\author{
Peter Temin ${ }^{\mathrm{a}, *}$, Hans-Joachim Voth ${ }^{\mathrm{b}, 1}$ \\ ${ }^{a}$ MIT and NBER, Department of Economics, 50 Memorial Drive, Cambridge, MA 02142, USA \\ ${ }^{\mathrm{b}}$ UPF, MIT and CEPR, Department of Economics, 50 Memorial Drive, Cambridge, MA 02142, USA
}

Received 31 January 2004

Available online 7 January 2005

\begin{abstract}
Crowding out during the British Industrial Revolution has long been one of the leading explanations for slow growth during the Industrial Revolution, but little empirical evidence exists to support it. We argue that examinations of interest rates are fundamentally misguided, and that the 18th- and early 19th-century private loan market balanced through quantity rationing. Using a unique set of observations on lending volume at a London goldsmith bank, Hoare's Bank, we document the impact of wartime financing on private credit markets. We conclude that there is considerable evidence that government borrowing, especially during wartime, crowded out private credit.
\end{abstract}

(C) 2004 Elsevier Inc. All rights reserved.

\section{Introduction}

How did government policy influence England's financial and economic development during the Industrial Revolution? Depending on the time period in question,

\footnotetext{
${ }^{*}$ Corresponding author. Fax: +1 6172531330.

E-mail addresses: ptemin@mit.edu(P.Temin),voth@mit.edu,joachim.voth@econ.upf.edu(H.-J.Voth).

${ }^{1}$ Present address: Economics Department + Centre de Receraca en Economia Internacional (CREI), UPF, c/Ramon Trias Fargas 25-27, E-08005 Barcelona, Spain. 
the existing literature suggests diametrically opposed answers. For the years before 1750, North and Weingast famously argued that government finance was central to the origins and course of the First Industrial Revolution. Better institutions and public debt management following the Glorious Revolution allegedly lowered risk premia and improved property rights (Acemoglu et al., 2002; North and Weingast, 1989). Subsequently, however, England's frequent wars during the 18th century-fought with the fiscal machine installed by William of Orange and his Dutch advisors - increased public debt. Williamson argued that wartime finance "crowded-out" private investment, slowing output growth (Williamson, 1984).

For all their intuitive appeal, evidence supporting both hypotheses has been scant. Many authors have examined changes in interest rates and the yield on private assets. Mokyr asserted that, "A logical corollary of the crowding-out hypotheses is that real interest rates should have risen for crowding out to occur" (Clark, 2001; Mirowski, 1981; Mokyr, 1987, p. 300; Quinn, 2001; Sussman and Yafeh, 2002). Price analysis is an attractive research strategy for economic historians; they can be as useful as quantities, and are often easier to collect (Antràs and Voth, 2003). We argue however that private-sector interest rates are not the right indicator of scarcity in the case of 18th-century finance - for both practical and conceptual reasons. In contrast to goods markets, where price is an efficient way of allocating scarce goods, credit markets rarely reach equilibrium through changes in interest rates alone. Since usury laws historically set a maximum interest rate below the market-clearing rate for private loans, rationing was the only way to restore equilibrium. Also, even in the absence of legal constraints, lenders had strong incentives to ration credit at lower rates. Hence, interest rates showed "excess stability." As Ashton put it: "the existence of this upper limit (on interest rates) is of the utmost importance to an understanding of the fluctuations of the period. Once the critical point had been reached further borrowing might become impossible" (Ashton, 1959).

The North-Weingast interpretation of England's rise is elegant, and it ties in with a growing literature on the institutional and financial determinants of development. Theoretical arguments strongly suggest that the Glorious Revolution ought to have played a role in the economy's initial transformation-historically, greater constraints on the executive often are correlated with higher growth (Acemoglu et al., 2001; DeLong and Shleifer, 1993). The same is true of financial development, as measured by the volume of intermediated finance, which appears to be robustly associated with higher per capita incomes in post-war samples, as well as during some historical periods (Levine and Zervos, 1998; Rajan and Zingales, 1998; Rousseau and Sylla, 2001). According to North and Weingast, the institutional changes following the Glorious Revolution made lending to the government a far safer proposition. Parliament's increasing influence and growing constraints on the executive translated into lower risk premia. This allowed for cheaper borrowing by the private sector, too (North and Weingast, 1989). Capital accumulation should thus have accelerated under William and the Hanoverian kings largely because of institutional change. According to the North-Weingast hypothesis, institutional change was the main reason why England became the first industrial nation, and finance was the key variable transmitting the benign effects of reform. 
Although North and Weingast showed that the volume of borrowing by the British government increased markedly without the recurring financial crises that were typical in other European countries, it remains doubtful whether political reform was crucial for lowering the cost of borrowing. Sussman and Yishay recently have compiled new time series of interest rates paid by the English government. They find little evidence that political reform influenced the rates at which the British government could borrow. Instead, armed conflict seems a much more important determinant of public interest rates (Sussman and Yafeh, 2002). Yet the main emphasis of the original North-Weingast argument was on capital investment, with the interest rate on government bonds as an indicator of the private cost of finance. Evidence for a decline in private-sector interest rates is far from abundant. Any change that did occur may have been obscured by the usury laws, which prescribed a maximum interest rate of $6 \%$ before 1714 and $5 \%$ percent thereafter. Thus, the "shadow" rate for private-sector borrowing may have moved markedly more than is suggested by the yield on consols. Quinn, examining loan transactions at a private bank in London, finds no evidence that the Glorious Revolution had an impact on interest rates charged (Quinn, 2001). To analyse the issue further, Clark collected data on asset returns obtained by charities. Rent charges and land rents, his principal sources, have the advantage that they were not subject to the usury laws, offsetting the disadvantage of not coming from financial markets. Between the 16th and the 18th century, both the return on rent charges and on land rents declined, but neither the civil war nor the Glorious Revolution left much of a trace in the series.

Similar problems with interest rates emerge from the debate on "crowding out," where available data on the scarcity of credit is insufficient to test the hypothesis conclusively (Williamson, 1987). Output growth per capita probably never exceeded $1.5 \%$ per annum between 1750 and 1850, and total factor productivity contributed no more than $0.5 \%$ for most of the period (Antràs and Voth, 2003; Crafts and Harley, 1992). The view that growth in Britain during the 18th and early 19th century was far slower than most scholars had assumed is now well-established, even if some implications remain puzzling (Temin, 1997). Yet the causes of relatively unspectacular growth are far less well understood. One interesting feature of the disappointing growth performance is the limited rate of capital accumulation. By 1830, the British economy had only managed to equip its workers, farmhands, and clerks with more or less the same number of tools, buildings, and desks that their great-grandfathers had used (Crafts, 1985; Harley, 1999). Williamson argued that relatively "slow" output growth during the Industrial Revolution may have been the result of massive government borrowing. According to this view, the frequent and costly wars that Britain fought during the 18th century were crucial in slowing down capital formation (Williamson, 1984). Government borrowing thus "crowded out" private investment; it was the Revolutionary Wars with France that stopped Britain's Industrial Revolution from turning into a growth spurt.

Hard evidence in favor of this argument has been hard to find. In his original contribution, Williamson calibrated a model of the British economy. Assuming a one-toone offset between public borrowing and private capital accumulation, he estimated very large effects from the French Wars. Real wages could have grown faster by $1.3 \%$ 
per annum, and growth of real income would have been $1.5 \%$ faster. Had Britain not decided to fight the French Republic, it could have grown twice as fast as it actually did. Critics were quick to point out that yields on consols did not show strong increases during wartime. Heim and Mirowski emphasized that nominal interest rates were somewhat higher during the Revolutionary Wars with France, but that real yields were lower (Heim and Mirowski, 1987; Heim and Mirowski, 1991). ${ }^{2}$ Again, charity returns do not show an impact of wartime financing.

In both the case of the North-Weingast hypothesis and the crowding-out argument, the changes in interest rates appear relatively small. The late Stuart kings had borrowed for about $2 \%$ more than their Hanoverian successors (Sussman and Yafeh, 2002). ${ }^{3}$ While a similar decline in private-sector interest rates probably would have caused some acceleration of growth and capital accumulation, it is hard to see that it could have initiated the broad-based transformation that got under way after 1700. Also, the differences between peacetime and wartime cost of finance during the late 18th centuries were not large enough to account for the drastic slowdown in growth claimed by Williamson. At the same time, "silent" crowding out due to the usury laws seems to be hard to prove (Clark, 1996). Indeed, some authors have concluded that the high elasticity of savings in 18th-century England can only be called "puzzling" (Clark, 2001; Ferguson, 2001). Neal rationalized the apparent absence of crowding-out as a result of international capital market integration. Foreign lenders, especially the Dutch, financed a substantial part of Britain's deficit, thus mitigating the effects on the domestic economy. This mechanism may have been particularly pronounced during the Revolutionary Wars, when Britain attracted flight capital from the continent (Neal, 1990, p. 216). We will test the importance of international capital flows later.

\section{Credit rationing and the stability of interest rates}

We propose a simple way of solving the elasticity-of-savings puzzle in this paper: credit rationing. If rationing was common, we should find that lending took place at a standardized rate, and that it did not respond to changes in economic conditions. Instead, the market should have balanced through quantity rationing. Credit rationing - the refusal of lenders to provide loans independent of the interest rate offeredis common in financial markets today. Asymmetric information is crucial-because borrowers willing to pay very high interest rates are inherently bad risks, banks need other ways of allocating credit than through changes in the interest rate charged. The more scarce reliable information about borrowers is, the harder it will be to differentiate rates at all (Jaffee and Stiglitz, 1990). As Stiglitz and Weiss argued, credit rationing probably accounts for a fair share of modern-day macroeconomic fluctuations (Jaffee and Stiglitz, 1990; Stiglitz and Weiss, 1981).

\footnotetext{
${ }^{2}$ This does not necessarily imply that borrowing costs were low-since contemporaries rightly expected deflation, high nominal interest rates probably translated into high ex ante real rates (Williamson, 1987).

3 The only exception is limited loans, secured in unusual circumstances (cf. North and Weingast, 1989).
} 
There is abundant indirect evidence that credit rationing was a key feature of 18th-century credit markets. In a famous passage from the Wealth of Nations, Adam Smith observed that (Smith, 1982 [1776], b. 2, c. 4.):

If the legal rate of interest in Great Britain, for example, was fixed so high as eight or ten per cent, the greater part of the money which was to be lent would be lent to prodigals and projectors, who alone would be willing to give this high interest. Sober people, who will give for the use of money no more than a part of what they are likely to make by the use of it, would not venture into the competition. A great part of the capital of the country would thus be kept out of the hands which were most likely to make a profitable and advantageous use of it, and thrown into those which were most likely to waste and destroy it.

Smith therefore suggested that usury limits were economically efficient. In 18thcentury Britain, adverse selection problems would have been substantial if interest rates had been allowed to rise to market-clearing levels. Private lenders should have found it advantageous to curtail lending and discriminate against borrowers who would have been willing to pay the market-clearing rate.

Ashton also questioned the usefulness of interest rates as an indicator of scarcity, and described the situation of the credit-market during wartime thus (Ashton, 1959):

It was not, then, simply through a rise in the cost of borrowing, but through interruptions to the flow of funds, that depression came to [the building and construction trade]. ... When the rate of 5 per cent had been reached builders and contractors might be getting all the loans they wanted, or, on the other hand, many of them might be in acute need of more. If we want to know the degree of scarcity we must look for other sources of information.

In the case highlighted by Ashton, a methodology that focuses exclusively on interest rates cannot shed much light on the crowding-out hypothesis and on the effects of institutional reform after 1688. Pressnell applied this reasoning to wartime, reporting that "war finance strained the resources and the patience at the Bank of England, causing it to ration discounts to the public at the end of 1795" (Pressnell, 1956).

Fig. 1 presents a simple model of quantity rationing. ${ }^{4}$ Assume that the market initially clears at $r_{0}$. Lending volume is equal to $Q_{0}$. With a demand shock that moves the demand curve outwards - such as public borrowing in wartime-lending volume should rise, and the loan market would balance at $r_{1}{ }^{5}$ If the legally permitted maximum is $r_{2}$, however, quantity will be rationed at $Q_{1}$. The shadow cost of capital $\tau_{1}$ will be markedly higher than $r_{2}$. This is the maximum interest rate that the last borrower would have been willing to pay if all his surplus was appropriated by

\footnotetext{
${ }^{4}$ Based on Jaffee and Stiglitz (1990). Their assumption that each bank earns quasi-rents from its knowledge of its customers and the volume of loans is less than in the competitive equilibrium is not relevant here.

5 This will depend on the extent to which borrowers are indifferent between the types of securities offered.
} 


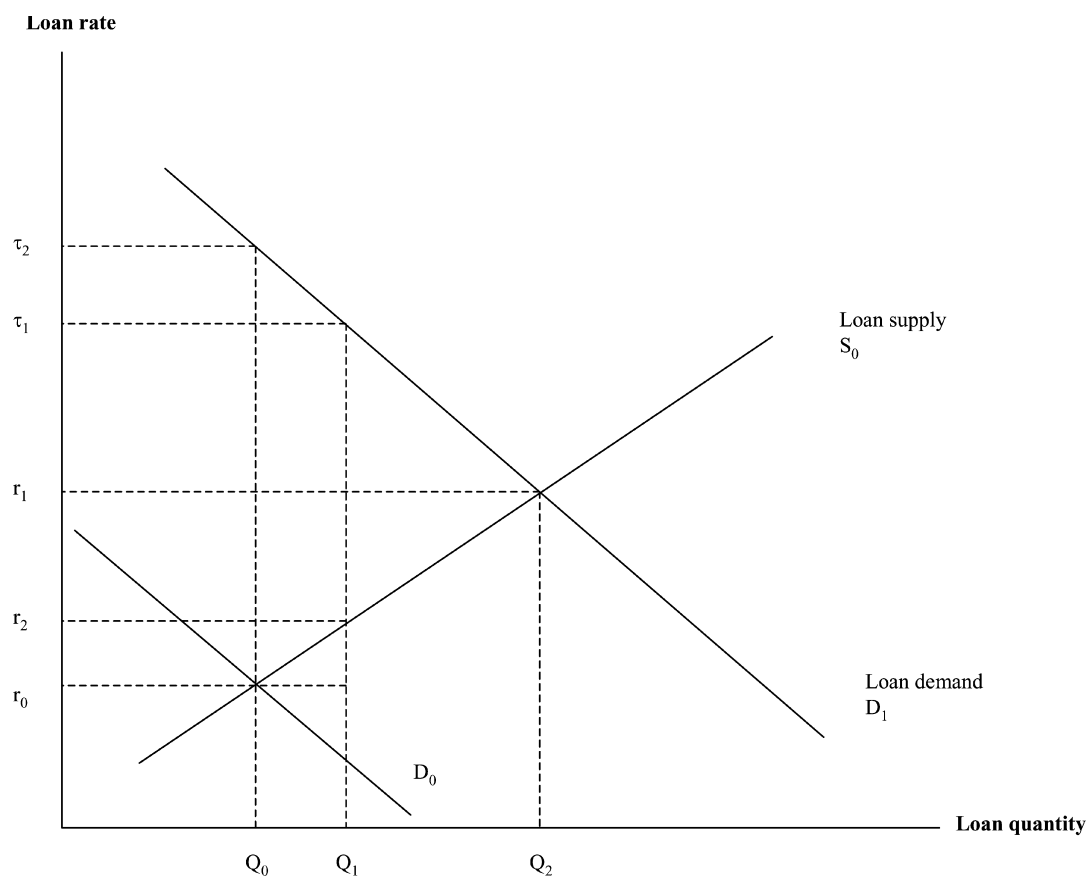

Fig. 1. A model of credit rationing.

the lender. Note that the smaller the increase in quantity and the smaller the increase of interest rates at which lending occurs, the larger the rise in the shadow rate will be. If interest rates had been close to the legal maximum before a demand shock, the loan market would have continued to supply $Q_{0}$ at $r_{0}$. The shadow rate would then have risen to $\tau_{2}$.

In a credit market characterized by the situation in Fig. 1, examining interest-rate changes such as the one from $r_{0}$ to $r_{1}$ is not very informative. To make sense of the role of government and government finance in England's economic development, we must take the possibility of quantity rationing seriously. We need information on the total volume of loans made.

Comprehensive information on aggregate lending volume is unavailable. Instead, we use the records of a West-End bank, Hoare's, to examine the issue of credit rationing. Hoare's Bank was (and is) a private bank in the West End of London. Initially founded by Richard Hoare, a goldsmith, it energetically moved into banking from the 1690s onwards. From 1702, Hoare's focused on lending and securities trading, shedding the remnants of its goldsmithing business (Temin and Voth, 2003, 2004). The bank soon acquired a select clientele that took out a variety of loans, from mortgages to securities lending and pawns against jewellery. By the 1730 s, it was lending more than $£ 150,000$ per year, and taking deposits of up to $£ 450,000$. Since 1702, Hoare's drew up annual balance sheets. Normally compiled in September, they summarize the bank's debts to depositors and the partners, its claims on 
borrowers, and holdings of silver and precious stones, of cash and securities. We collected the balance sheets from 1702 to 1862, except for a few missing years near the beginning of our period. The reporting format varied, but it almost always contained information on total lending volume, total deposits, and cash reserves.

The bank was, of course, only one of several such institutions involved in credit intermediation. In addition to other banks, scriveners offered intermediation services similar to those provided by French notaries, and much lending took the form of trade credit and personal lending (Hoffman et al., 2000; Richards, 1929). Joslin estimated that there were 13 "West End" bankers in 1725, and 15 in 1785, and that the total number of banks in London rose from 24 to 52 over the period. These are conservative, lower bound estimates. As early as 1770, some scholars calculate the total number of London banks to be as high as 42 (Quinn, 1997).

We cannot know with any accuracy how representative Hoare's Bank was. The bank's longevity itself suggests that it may not have been typical. It also operated in the capital city, close to the seat of government and the government debt market. The bank's location suggests that it may have been more exposed to government-induced scrambles for liquidity. We can test for similarities for a small subset of years - from 1844, we have the volume of deposits held by the public and by bankers at the Bank of England. If we apply the same methods of separating trend from cycle as in the rest of the paper, we find a positive correlation coefficient of 0.38 with Hoare's deposits, significant at the $10 \%$ level (Mitchell, 1971, p. 658). ${ }^{6}$ There is no evidence that deposits at Hoare's are more volatile - the standard deviation of deviations from trend are very similar. This, of course, cannot tell us how representative Hoare's bank was for the period before 1844, which is key for the crowding-out issue. Yet it makes it less likely that the bank's business was driven by forces fundamentally different than those operating throughout the financial system as a whole.

In any case, we lack similar records from other banks in the 18 th century. We study Hoare's Bank because it is the only one with extant records. ${ }^{7}$ We believe that the best way forward is a number of studies using firm-level evidence; this paper is partly an attempt to stimulate further research and data collection that can allow corroboration or refutation of our hypothesis that lending at Hoare's was broadly representative of economy-wide patterns.

Was Hoare's rationing credit? Our first piece of evidence comes simply from the distribution of interest rates. Fig. 2 shows the distribution of lending rates with the individual loans as the unit of observation. In the early 18 th century, Hoare's made

\footnotetext{
${ }^{6}$ The strongly upward trend over these years should not drive our results; hence the separation of trend and cycle by using the deviations of log deposits from trend and trend squared (as below). We also experimented with an error-in-variables regression, with deposits at Hoare's as the dependent variable and at the BOE as the explanatory variable, and a noise to signal ratio of 0.5 . This suggested a coefficient of 0.68 on log deposits at the BOE, which is no longer significantly different from unity (but strongly different from zero).

7 The data from Child's analysed by Quinn may be used in similar fashion. Since there appear to be no surviving balance sheets, this will require the reconstruction of aggregate lending figures for each year from individual loan transactions, and requires that any degree of archival loss is constant over time (cf. Quinn, 2001).
} 


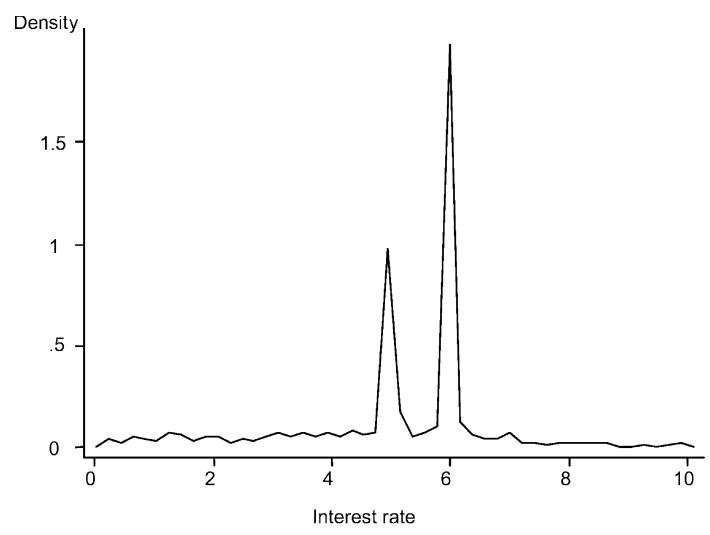

Fig. 2. Distribution of interest rates.

$92 \%$ of all loans against interest at the usury limit - $6 \%$ up to 1714 , and $5 \%$ thereafter (Temin and Voth, 2003). Qualitative evidence reinforces the view that quantity rationing was frequent. Hoare's bank told one of its clients who sought to take out a loan that, independent of the conditions offered, it could not extend credit (Brewer, 1989): ${ }^{8}$

At present we do not advance Money to anyone on any security...The uncommon supply of millions and millions granted and now raised [to pay for the Seven Years' War] obliges all of our Profession to be prepared for the Payments [to customers moving their money from the bank into government stock] coming on, so that instead of lending out money, we have called it in on this occasion.

In a situation like the one described in Hoare's letter to its customer, there is little reason to believe that private interest rates yield much information on the availability and cost of credit. We find that Hoare's acted in way that is compatible with the argument set out in its letter-during wartime, it kept $29.5 \%$ of its assets in cash, compared to $25.1 \%$ during peacetime. Two channels may have been crucial for transmitting government borrowing shocks to the financial system. First, as described by Hoare's, customers may have switched their savings from bank deposits to government debt. At a time when banks habitually refused to pay any interest on deposits, government bonds yielding approximately 3-6\% must have seemed an attractive alternative. Second, the partners at Hoare's may have invested some of their capital in bonds rather than in the bank. This would have led them to restrict loans additionally.

\footnotetext{
${ }^{8}$ Other reasons may have inclined Hoare's not to lend to the client in question. The bank may have chosen a convenient excuse. Yet the fact that the general credit restriction brought on by government borrowing was seen as a plausible reason not to lend tells us that many other financial institutions may have followed similar practices.
} 
In both cases, we should observe less lending by a private bank like Hoare's whenever the government's borrowing requirements increased markedly. The balance sheets, combined with information on the public debt of the United Kingdom, allow us to test this hypothesis in more detail.

In our attempt to trace credit rationing, as exemplified by the case of Hoare's, we argue for the following simple causal chain: higher wartime borrowing simultaneously increased the availability of liquid government debt and raised the price of borrowing. As clients used their accumulated deposits to purchase government debt, banks lent less. Since almost all lending was at the maximum rate allowed by the usury laws, this did not become apparent in higher rates on private loan transactions. Instead, lending volume contracted, as less desirable (or less well-connected) borrowers lost access to credit. In addition, the bank may have decided to hold government debt instead of lending to private individuals or firms.

\section{Government borrowing and private lending: evidence from Hoare's}

To separate trend from cycle for all our variables, we regress the log of each variable $Z$ on a constant, a time trend, and the trend squared (to capture non-linearities):

$$
\log Z=C+\alpha T+\beta T^{2}+\varepsilon .
$$

This simple setup allows us to explain $94 \%$ of the total variation in lending volume. In our analysis, we will mainly use the residuals $\varepsilon$ of Hoare's lending volume (HGAP), of government debt (DebtGAP), and of industrial output (QGAP). We use these variables in the quantitative analysis below. Because of missing observations on the size of Hoare's balance sheet and because of our focus on the period of the industrial revolution, we use data from 1720 onwards.

The top panel of Fig. 3 gives an impression of the growth of Hoare's business. The bottom panel shows the type of shocks (HGAP) that need to be explained. Hoare's lending against interest grew from $£ 50,000$ in 1702 to over $£ 2,000,000$ in 1860 . The rise parallels the increase in total output in the British economy over the period, and suggests higher demand for intermediation services. This long, continuous upward trend in total lending was sometimes checked or even reversed by conditions in any one year, by the vagaries of a family business where a partner's death can lead to changes in the bank's equity, and the political situation.

To examine the impact of wartime financing, in Fig. 4 we plot the lending residual HGAP alongside the growth of public debt (DebtGAP). While lending fluctuates with greater frequency, the overall impression is one of a strong, inverse correlation between lending and debt growth. At the very beginning of the period, during the War of the Spanish Succession, lending growth relative to trend was lacklustre. There is ample evidence that massive government borrowing was an important contributing factor, even if some of the slowdown must be attributed to factors specific to Hoare's bank itself (Temin and Voth, 2003). During the War of Jenkin's Ear and the Wars of the Austrian Succession, lending growth relative to trend slowed, but the 


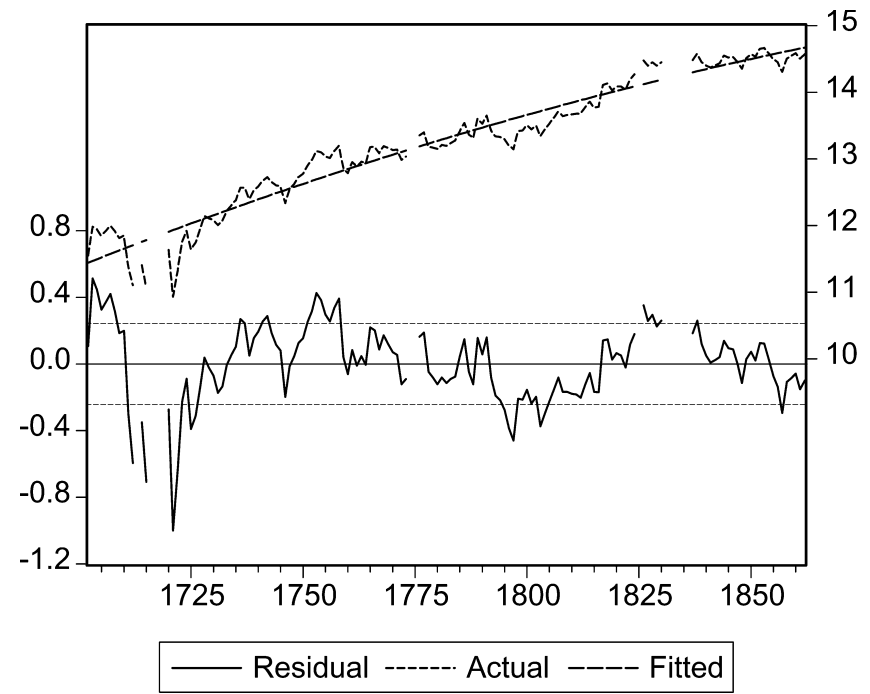

Fig. 3. Lending volume at Hoares, trend and residual (HGAP).

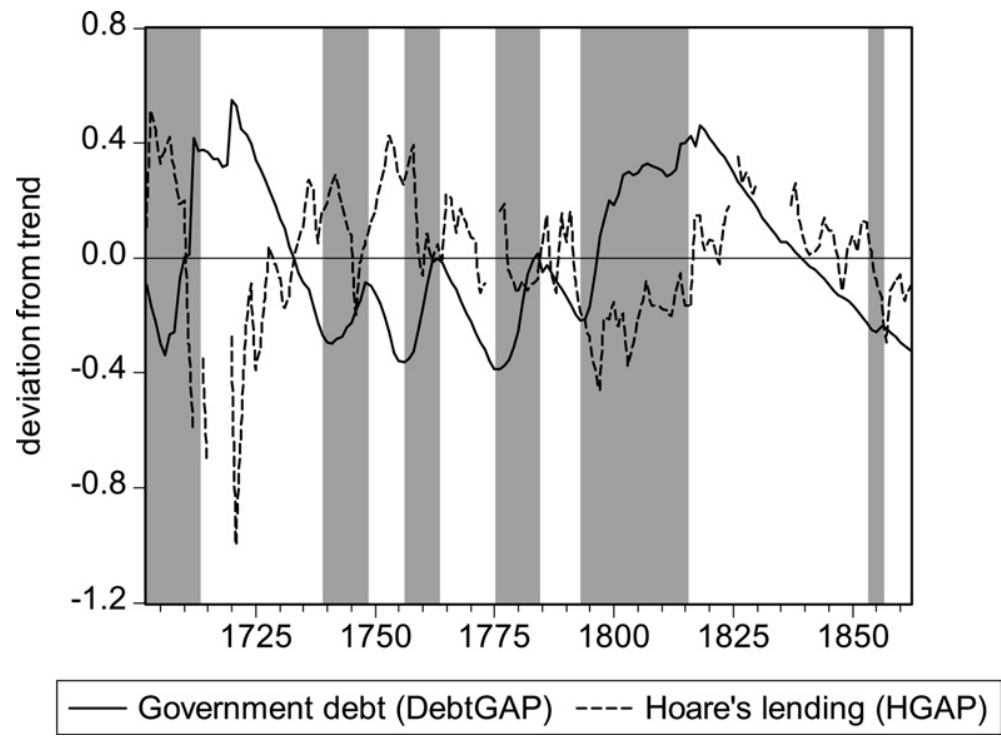

Fig. 4. Government debt and lending at Hoare's-deviations from trend.

gap never became dramatic. The Seven Years War shows a much more striking deceleration, as does the War of American Independence in the 1770s and early 1780s. During the Revolutionary and Napoleonic Wars, lending fell in absolute terms for a number of years. Relative to the secular trend, there was a very marked 


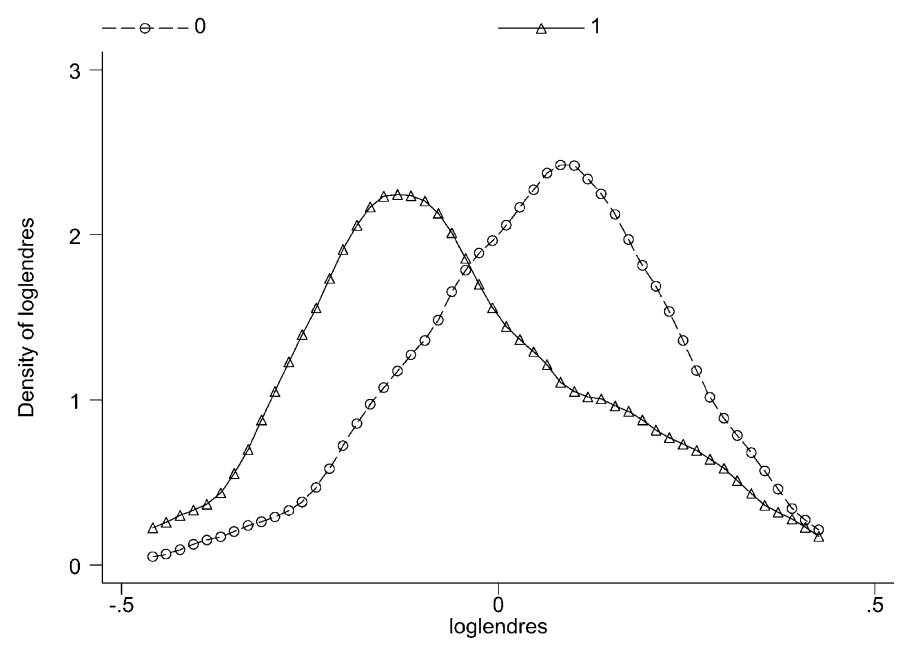

Fig. 5. Lending volume at Hoares (HGAP), wartime $(=1)$ and peacetime $(=0)$.

downturn. A similar, sudden - if much less sustained - fall occurred during the Crimean War in the 1850s. By no measure did all sudden reversals coincide with the outbreak of war, but Fig. 4 suggests that declines may have been much more common in wartime. Sixty-eight percent of war-years showed a negative deviation from trend, but only $37 \%$ of peacetime years did - the HGAP variable is twice as likely to take on negative values during war than during peacetime. ${ }^{9}$

A simple $t$ test reveals the extent to which lending at Hoare's suffered from the negative shocks of wartime - the average lending residual in non-war years is $£ 49,710$ vs. -8648 during wartime. Lending declined by $5 \%$ on average when Britain found itself at war, and grew by $4.1 \%$ during peacetime. The difference is significant at the $99 \%$ level. Shocks during wartime are primarily negative, while shocks during peacetime were largely positive. In Fig. 5, we plot the smoothed distributions of lending volume (HGAP) to show the gap between actual lending and trend lending at Hoare's, conditional on whether or not the country is at war. ${ }^{10}$ The median change in lending in a war year was $-8.1 \%$; in peacetime, it was $5.6 \%{ }^{11}$

To describe the evolution of lending, we briefly examine correlations between our main variables (Table 1). Public sector interest rates were correlated both with the growth rate of lending at Hoare's and the bank's cash ratio. Not surprisingly, high interest rates were correlated with high debt volumes and wars. More importantly for this paper, high interest rates were associated with slowdowns in the growth of industrial production.

\footnotetext{
${ }^{9} \mathrm{~A} \chi^{2}$ test suggests that the difference is significant at the $1 \%$ level.

${ }^{10}$ We use a non-parametric technique (Epanechnikov kernel density estimation) for smoothing.

11 The visual impression from Fig. 5 is confirmed by a median regression. We find a coefficient of minus 0.14 , with a $t$-statistic of 3.85 . For methodological background, see Koenker and Hallock (2001).
} 
Table 1

Correlations of key variables, $1720-1862$

\begin{tabular}{lccccc}
\hline & $i_{\text {composite }}$ & HGAP & Cash/assets & DebtGAP & QGAP \\
\hline HGAP & $-0.54^{* * *}$ & & & & \\
Cash/Assets & $0.36^{* * *}$ & $-0.37^{* * *}$ & & & \\
DebtGAP & $0.42^{* * *}$ & $-0.39^{* * *}$ & 0.09 & & \\
QGAP & $-0.67^{* * *}$ & $0.27^{* *}$ & -0.11 & -0.43 & $-0.37^{* *}$ \\
WAR & $0.49^{* * *}$ & $-0.22^{* * *}$ & $0.39^{* * *}$ & -0.12 & $-0.49^{* *}$ \\
Equity & 0.12 & 0.32 & -0.28 & $-0.42^{*}$ & \\
\hline
\end{tabular}

Notes. ${ }^{*, * *, * * *}$ indicate significance at the 10,5 , and $1 \%$ level of confidence. $t$-statistics calculated on the basis of heteroscedasticity-consistent standard errors.

$i_{\text {composite }}$ is derived from the marginal borrowing rate excluding terminable loans in Sussman and Yafeh (2002), spliced to the consol rate (after 1731), HGAP is deviation of log lending volume at Hoare's from a quadratic trend, as depicted in Fig. 3. DebtGAP is the deviation of log government debt from a quadratic trend, based on the data from Mitchell (1971, p. 600), QGAP is deviation of log industrial output from a quadratic trend, with the annual series taken from Crafts and Harley (1992), WAR is a dummy variable that takes the value of 1 during wartime, and 0 otherwise. Equity is partner's equity in the firm.

Hoare's lending also is correlated with the other variables in ways that suggest we can use this single bank as a proxy for more general credit conditions. To be sure, it is heroic to assume that Hoare's is broadly representative of all banks. But since there are no other data on private lending volumes, we make this assumption out of necessity, not by choice. We explore some of the possible biases below.

The strong decline of lending growth during years of massive government borrowing should not come as a surprise. Since the median length of a loan at Hoare's was 281 days, the bank could influence its total lending relatively quickly - calling in loans or refusing credit, as described in its letter to its prospective client. For the first 40 years, we can easily separate deposits from partners' equity. Customers' funds fell significantly when government borrowing increased. Since the bank did not pay interest on deposits, it had no reason to turn depositors away. The decline in loanable funds offers a ready explanation for the negative correlation of lending with government borrowing. Equity is not significantly correlated with interest rates or Hoare's lending. Higher public debt is negatively correlated with partners' equity, but this correlation, while statistically significant, depends crucially on a handful of observations. We only have data on the firm's equity for 1702-24, and the results consequently have to be treated with care. Equity rose and fell with the death of partners and the entry of new ones, but competition by the public purse for funds may have been an additional factor. ${ }^{12}$

For more systematic tests, we use the lending gap depicted in Fig. 3 as the dependent variable in our regressions, taking the overall upward trend of lending over the century-and-a-half between 1702 and 1862 as given. This has the added benefit that our dependent variable is stationary. In Table 2 , we use a variety of specifications to demonstrate the robustness of the link between government borrowing and private lending. We estimate

\footnotetext{
${ }^{12}$ The data are described in greater detail in Temin and Voth (2003).
} 
Table 2

The impact of war on lending volume at Hoare's-OLS and NLS estimates

\begin{tabular}{|c|c|c|c|c|c|c|c|c|}
\hline & 1 & 2 & 3 & 4 & 5 & 6 & 7 & 8 \\
\hline $\operatorname{AR}(1)$ & & & & & $\begin{array}{l}0.74^{* * *} \\
(12.9)\end{array}$ & $\begin{array}{l}0.77^{* * *} \\
(14.0)\end{array}$ & $\begin{array}{l}0.72^{* * *} \\
(11.4)\end{array}$ & $\begin{array}{l}0.85^{* * *} \\
(17.8)\end{array}$ \\
\hline$i_{\text {composite }}$ & $\begin{array}{l}-0.15^{* * *} \\
(7.4)\end{array}$ & & & & $\begin{array}{l}-0.17^{* * *} \\
(6.0)\end{array}$ & & & \\
\hline War & & $\begin{array}{l}-0.09^{* *} \\
(2.5)\end{array}$ & & & & $\begin{array}{l}-0.026 \\
(0.64)\end{array}$ & & \\
\hline$i_{\text {consols }}$ & & & $\begin{array}{l}-0.15^{* * *} \\
(8.9)\end{array}$ & & & & $\begin{array}{l}-0.14^{* * *} \\
(5.5)\end{array}$ & \\
\hline DebtGAP & & & & $\begin{array}{l}-0.34^{* * *} \\
(5.1)\end{array}$ & & & & $\begin{array}{l}-0.299^{*} \\
(1.84)\end{array}$ \\
\hline Estimator: & OLS & & & & Marquarc & NLS & & \\
\hline Adj. $R^{2}$ & 0.28 & 0.04 & 0.39 & 0.16 & 0.69 & 0.60 & 0.72 & 0.72 \\
\hline LM & $81.2^{* * *}$ & $22.4^{* * *}$ & $12.7^{* * *}$ & $20.3^{* * *}$ & $7.8^{* *}$ & 1.08 & 0.38 & 0.93 \\
\hline
\end{tabular}

Note. ${ }^{*, * *, * * *}$ indicate significance at the 90,95 , and $99 \%$ level of confidence. $t$-statistics calculated on the basis of heteroscedasticity-consistent standard errors.

Dependent variable is the deviation of log lending from trend.

Sample period is 1720-1862, except for Eqs. (3) and (7), where data availability requires us to start in 1731.

$$
\mathrm{HGAP}=C 1+\alpha X+e,
$$

where HGAP is the residual from Fig. 3, $C 1$ is the intercept, $X$ is one of the exogenous variables, and $e$ is the error term.

Table 2 shows the impact of more costly government debt service and wartime conditions on lending volume at Hoare's Bank. We use two interest rate series. The yield on consols and similar instruments is only available from $1730 .{ }^{13}$ For the period before that date, we use the series compiled by Sussman and Yafeh which gives the ratio of debt service to debt outstanding, excluding payments for terminable loans. We splice the series in 1731 to derive one overall series for the cost of government debt service. In addition, we experiment with using the consol rate only. For every percentage point extra, lending at Hoare's declined by $14-17 \%$ more than it otherwise would have done. The impact is broadly speaking unchanged between the longer interest series and the one for consols, which suggests a slightly greater impact. During wartime, lending is about $9 \%$ lower than normal. This tallies well with the fact that consol rates during wartime are two-thirds of a percentage point higher on average than during peacetime. Debt increases above trend depress lending strongly and significantly.

The OLS estimates appear to suffer from serial correlation-Lagrange multiplier tests strongly reject the null of no autocorrelation in the error term. Hence, we also use the Marquardt NLS estimator. It yields similar coefficients on the interest rate variables and confirms their statistical significance. The coefficient on war now drops

\footnotetext{
${ }^{13}$ We use data from Sussman and Yafeh (2002). We thank Nathan Sussman and Yishay Yafeh for kindly making their data available. Their data on consols include annuity rates for the period 1730-1753.
} 
substantially and is no longer significant, but this may be an artefact of the estimation method and the correction procedure for serial correlation.

Implicitly, we assume that Hoare's lending data are a useful proxy for overall credit conditions. Yet in actual fact, they will not have moved in lock-step with lending at Hoare's: TGAP $=$ HGAP $+v$, where TGAP is the deviation of aggregate lending from trend. As long as $v$ is uncorrelated with HGAP, OLS will yield unbiased estimates of the parameters in (1) - we are effectively just adding another error term. On the other hand, if $v$ is correlated with any of the exogenous variables, OLS will be inconsistent and biased, and we will over- or underestimate $\alpha$.

In estimating Eq. (1), we also assumed that the interest rate on government borrowing was unaffected by lending at Hoare's and its peers - the error term $e$, we implicitly argued, is uncorrelated with any of the explanatory variables. This is probably correct for the war dummy, but the borrowing rate for the government could be correlated with the error term. If a savings "shortage" because of, say, competing Dutch borrowing or the South Sea bubble pushed up the public interest rate, this may also have made it harder for Hoare's to obtain deposits and lend. We would be falsely attributing this change to the government if borrowing had increased at the same time. The bias could also point in the opposite direction, with economic growth raising the marginal product of capital, stimulating loan demand, and reducing government borrowing due to higher tax revenues. If interest rate shocks for government debt were partly driven by higher borrowing demand from the private sector, then we will have estimated a lower bound on the true effect of government borrowing.

To sidestep these issues, we do two things. First, we try to control for macroeconomic conditions, by including the index of industrial output growth in our regressions. ${ }^{14}$ Second, we use an instrumental variables approach, and jointly estimate:

$$
\begin{aligned}
& \mathrm{HGAP}=C 1+\alpha i+\beta \mathrm{QGAP}+e, \\
& i=C 2+\alpha W+\delta \mathrm{QGAP}+u,
\end{aligned}
$$

where $i$ is the government borrowing rate, QGAP is the deviation of log output from trend, $W$ is a war dummy, and $e$ and $u$ are error terms (Table 3 ). The second equation identifies the component of $i$ that is driven by government wartime borrowing. This is then used to explain lending shocks at Hoare's bank, using two stage least squares (TSLS) for estimation. In addition to simply using the war dummy, we also use government borrowing as an instrument for the interest rate. The underlying assumption is that lending at Hoare's was not influenced by public borrowing or war in any way other than through the effect on public interest rates or borrowing volume.

We find broadly similar coefficients on public sector interest rates than under OLS, with lending declining by $11-26 \%$ for every additional 100 basis points of debt

\footnotetext{
${ }^{14}$ We use the revised best guess, as compiled by Crafts and Harley (1992) (Table 3.1).
} 
Table 3

IV estimates of the impact of government borrowing on private lending

\begin{tabular}{lllllllll}
\hline Equation & 1 & 2 & 3 & 4 & 5 & 6 & 7 & 8 \\
\hline AR(1) & $0.73^{* * *}$ & $0.73^{* * *}$ & $0.73^{* * *}$ & $0.74^{* * *}$ & $0.73^{* * *}$ & $0.71^{* * *}$ & $0.83^{* * *}$ & $0.75^{* * *}$ \\
& $(13.1)$ & $(12.3)$ & $(11.82)$ & $(11.0)$ & $(11.9)$ & $(10.9)$ & $(2.3)$ & $(10.6)$ \\
$i_{\text {composite }}$ & $-0.11^{*}$ & & -0.11 & & $-0.11^{*}$ & & $-0.22^{* *}$ & \\
& $(1.75)$ & & $(1.49)$ & & $(1.9)$ & & $(2.3)$ & \\
$i_{\text {consols }}$ & & $-0.14^{* * *}$ & & $-0.26^{* *}$ & & $-0.14^{* * *}$ & & $-0.16^{* * *}$ \\
& & $(3.2)$ & & $(2.4)$ & & $(3.0)$ & & $(3.05)$ \\
QGAP & & & 0.17 & -1.5 & & & -1.84 & -0.15 \\
& & & $(0.48)$ & $(1.2)$ & & & $(1.1)$ & $(0.5)$ \\
Instrument & WAR & WAR & WAR & WAR & Dgap & Dgap & Dgap & Dgap \\
Adj. $R^{2}$ & 0.68 & 0.72 & 0.68 & 0.63 & 0.68 & 0.72 & 0.58 & 0.71 \\
\hline
\end{tabular}

Note. ${ }^{*, * * * * *}$ indicate significance at the 90,95 , and $99 \%$ level of confidence. $t$-statistics calculated on the basis of heteroscedasticity-consistent standard errors.

Dependent variable is HGAP.

Sample period is 1720-1862, except for Eqs. (2), (4), (6), and (8), where data availability requires us to start in 1730 .

service. This suggests that some of the positive shocks to interest rates that were not driven by war were less inimical to bank lending and intermediation - it could be the case that some of these interest rate increases reflected growing demand for privatesector credit. The effect is stronger and more significant when we use the consol rate as an explanatory variable. This is most likely driven by the nature of our data- the earlier interest rate series based on average interest payments relative to debt, while comparable, is not exactly a yield series. For the period that matters for our argument, the years after 1750, the consol series suggests strong negative effects of government borrowing on private lending. Including changes in industrial output appears to make little difference to our estimates. Given that the average difference in public sector interest rates between war- and peacetime was 62 basis points, the results in Table 3 suggest an average drop of lending below its trend value by $7-16 \%$.

Williamson assumed that there was 1:1 "crowding out" between private lending and government borrowing. Our estimates in Table 2 suggest a range of 0.20 0.34, smaller than Williamson's estimate but still substantial. Since some of our right-hand side variables may be endogenous, it is natural to use a VAR approach to examine the impact of government borrowing on growth

$$
\begin{aligned}
\operatorname{HGAP}_{t}= & a_{11} \operatorname{HGAP}_{t-1}+a_{12} \operatorname{HGAP}_{t-2}+a_{13} \operatorname{HGAP}_{t-3}+b_{11} \operatorname{DebtGAP}_{t-1} \\
+ & b_{12} \operatorname{DebtGAP}_{t-2}+b_{13} \operatorname{DebtGAP}_{t-3}+c_{1}+\varepsilon_{1 t}, \\
\text { DebtGAP }_{t}= & a_{21} \operatorname{DebtGAP}_{t-1}+a_{22} \operatorname{DebtGAP}_{t-2}+a_{23} \operatorname{DebtGAP}_{t-3} \\
& +b_{21} \operatorname{HGAP}_{t-1}+b_{22} \operatorname{HGAP}_{t-2}+b_{23} \operatorname{HGAP}_{t-3}+c_{2}+\varepsilon_{2 t} .
\end{aligned}
$$

In this way, using non-structural estimation, we impose few constraints, and allow for feedback effects from, say, higher private-sector lending (as a result of buoyant loan demand during good time) to lower government borrowing. We estimate with 


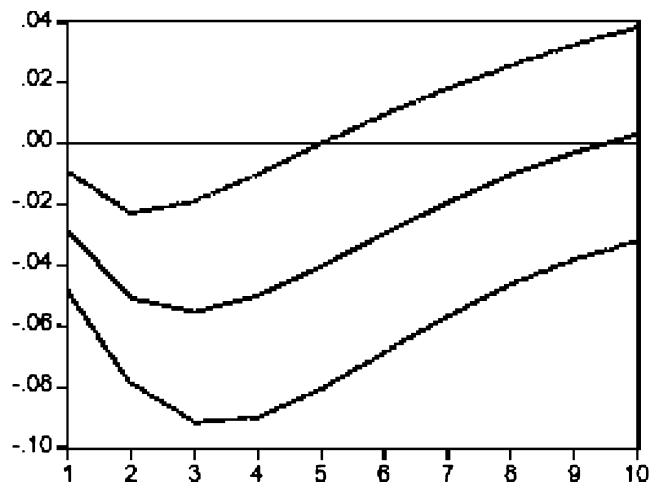

Fig. 6. Response of HGAP to Choletsky one SD innovation of DebtGAP.

3 lags. ${ }^{15}$ The impulse response function for lending is plotted in Fig. 6. A one standard deviation increase of the government's debt stock (equivalent to $8 \%$ ) reduced lending by $3 \%$ in the first year, by $5 \%$ in the second year, and by $5.5 \%$ in the third year. The effect remains statistically significant for the first 4 years. This suggests that Britain's wars represented a major shock to the nascent system of credit intermediation, and that its effects were strongly negative. The true impact over several years therefore may well be closer to unity.

\section{Credit rationing and economic growth}

Using firm-level data on lending volumes, we find clear evidence of credit rationing as a result of wartime borrowing. This is a necessary step towards showing that "crowding out" was important, but it is not sufficient. Did it matter for Britain's economic performance? We emphasize two facts.

First, higher debt growth coincided with slower output growth. Fig. 7 shows the extent to which the two time series moved inversely over the 18th and 19th century. We use the industrial output series compiled by NFR Crafts and Knick Harley (Crafts and Harley, 1992). Higher debt growth especially during the War of the Austrian Succession, the Seven Years War, the War of American Independence, and the Napoleonic Wars went hand-in-hand with lower output growth. After the battle of Waterloo, the inverse relationship largely disappears. Relative to trend, the industrial sector of the British economy grew on average by 3.1\% during peacetime, and by $-4.6 \%$ during wartime.

Second, the decline in lending volumes during wartime was probably large enough to account for the marked slowdown, as argued in Section 3. Conclusive proof of a connection is almost impossible, but we can examine some of the circumstantial evi-

\footnotetext{
${ }^{15} \mathrm{We}$ orthogonalize the responses by using the Cholesky decomposition, and the ordering (DebtGAP, HGAP).
} 


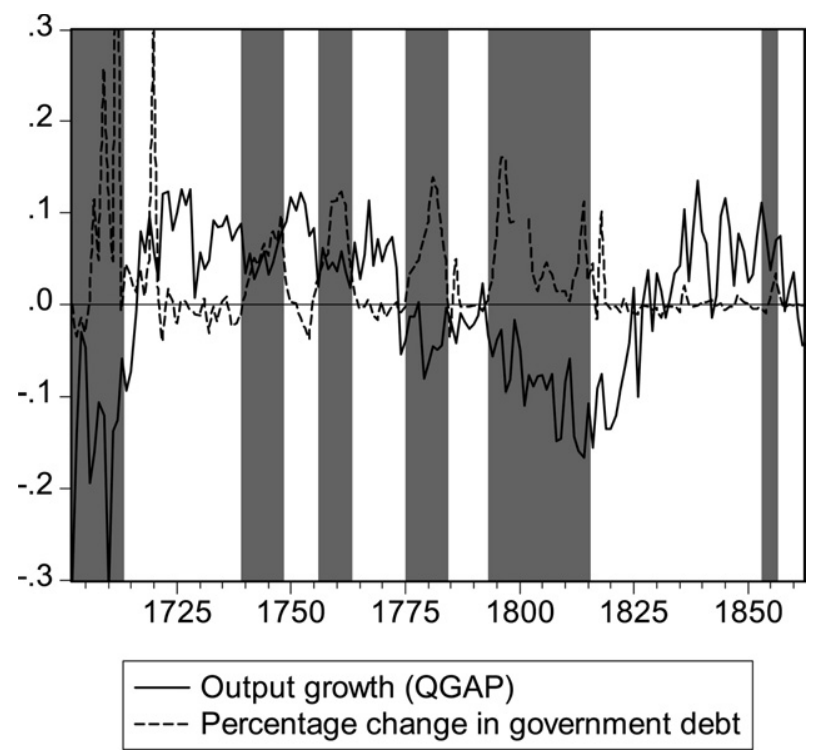

Fig. 7. Output growth and government debt.

dence. We of course do not have data on aggregate private lending. Instead we use the detrended lending volume at Hoare's as a proxy for the aggregate. In years when lending at Hoare's was above trend, the difference between industrial output growth in wartime and in peacetime is small and not significant - a mere $0.5 \%$ (Table 4). When lending was below trend, however, growth overall was slower, and the difference between years with and without armed conflict was pronounced-9\%. We therefore have some evidence that Britain's wars were indeed bad for the growth of industrial output, and that the transmission of the shock depended partly on

Table 4

Industrial output growth during wartime and peacetime

\begin{tabular}{lccc}
\hline & Entire period & HGAP $\geqslant 0$ & HGAP $<0$ \\
\hline During & & & \\
Peacetime & 0.032 & 0.032 & 0.033 \\
& $(89)$ & $(61)$ & $(28)$ \\
Wartime & -0.024 & 0.037 & -0.06 \\
& $(53)$ & $(18)$ & $(35)$ \\
Difference & 0.056 & -0.005 & 0.09 \\
$t$ test & & 0.28 & 5.3 \\
Significance & 4.73 & 0.78 & 0.0001 \\
\hline
\end{tabular}

Note. Number of observations in parentheses; sample period is $1720-1862$. $t$-statistics calculated on the basis of heteroscedasticity-consistent standard errors.

Dependent variable is QGAP

${ }^{\text {a }}$ Assuming equal variances. 
the process of credit intermediation. When lending collapsed, growth was slow in general, and wartime coincided with a fall in production; when it held up more or less well, growth was more rapid and even years of military conflict did little to dent the rise of the First Industrial Nation. ${ }^{16}$

A closer look at the distributions suggests that it is mainly "growth disasters" that are responsible for the results in Fig. 6. During wartime, $85 \%$ of the output deviations are negative if lending was below trend. If it was above trend, fewer than half of the years in our sample recorded negative deviations of output growth.

One simple test of the proposed link explaining the slowdown runs from greater borrowing to higher interest rates on government bonds and hence slower industrial output growth. Table 5 investigates the basic patterns. A rise in interest rates almost always coincided with a slowdown in growth. The result holds independent of the estimation technique used and the specification of the interest rate variable. We also find a direct effect of war; since conflict (and its effects) typically lasted for more than 1 year, the serial-correlation correction has difficulty estimating the effect precisely. Crucially, we find that higher government borrowing slowed industrial growth. We use the deviations from log trend, as in the earlier analysis, as well as growth rates of government debt. The latter exhibit the same short-run volatility as the output series and consequently contain more information that we can exploit to pin down the relationship. We find that, on average, a $1 \%$ rise in interest rates slowed growth by $4-7 \%$, and that for every $10 \%$ increase in government debt, industrial output fell by $2-4 \%$ below trend.

The evidence presented in Fig. 6 and in Tables 4 and 5 is suggestive. "Crowdingout" as an explanation of slow growth during Britain's Industrial Revolution will be strengthened if we can show that lower lending volume was sufficient to produce a marked slowdown in growth, and if output growth responded quickly to changes in lending. If lending at Hoare's was broadly representative of that at other banks, then the rationing effects found earlier can be used to infer the overall impact of more government spending.

The same VAR method used earlier can be employed to investigate the effects of government borrowing on national output (industrial production) more directly, again using three lags

$$
\begin{aligned}
& \mathrm{QGAP}_{t}=a_{11} \mathrm{QGAP}_{t-1}+a_{12} \mathrm{QGAP}_{t-2}+a_{13} \mathrm{QGAP}_{t-3}+b_{11} \text { DebtGAP }_{t-1} \\
& +b_{12} \text { DebtGAP }_{t-2}+b_{13} \operatorname{DebtGAP}_{t-3}+c_{1}+\varepsilon_{1 t} \text {, } \\
& \text { DebtGAP }_{t}=a_{21} \text { DebtGAP }_{t-1}+a_{22} \text { DebtGAP }_{t-2}+a_{23} \text { DebtGAP }_{t-3} \\
& +b_{21} \mathrm{QGAP}_{t-1}+b_{22} \mathrm{QGAP}_{t-2}+b_{23} \mathrm{QGAP}_{t-3}+c_{2}+\varepsilon_{2 t} \text {. }
\end{aligned}
$$

\footnotetext{
${ }^{16}$ Note that this is not driven by many of the observations for positive lending gaps coming from the period after the end of the Napoleonic wars we have 21 wartime observations from the 18 th century in the sample with $\mathrm{HGAP} \geqslant 0$.
} 
Table 5

The impact of war on industrial output growth (QGAP) - OLS and NLS estimates

\begin{tabular}{|c|c|c|c|c|c|c|c|c|c|c|}
\hline & 1 & 2 & 3 & 4 & 5 & 6 & 7 & 8 & 9 & 10 \\
\hline $\operatorname{AR}(1)$ & & & & & & $\begin{array}{l}0.77 \\
(13.96)\end{array}$ & $\begin{array}{l}0.83^{* * *} \\
(17.8)\end{array}$ & $\begin{array}{l}0.73^{* * *} \\
(11.74)\end{array}$ & $\begin{array}{l}0.81^{* * *} \\
(15.6)\end{array}$ & $\begin{array}{l}0.83^{* * *} \\
(17.99)\end{array}$ \\
\hline$i_{\text {composite }}$ & $\begin{array}{l}-0.065^{* * *} \\
(10.47)\end{array}$ & & & & & $\begin{array}{l}-0.03^{* * *} \\
(3.5)\end{array}$ & & & & \\
\hline War & & $\begin{array}{l}-0.05^{* * *} \\
(4.7)\end{array}$ & & & & & $\begin{array}{l}-0.02 \\
(1.3)\end{array}$ & & & \\
\hline$i_{\text {consols }}$ & & & $\begin{array}{l}-0.07^{* * *} \\
(12.4)\end{array}$ & & & & & $\begin{array}{l}-0.04^{* * *} \\
(4.22)\end{array}$ & & \\
\hline DebtGAP & & & & $\begin{array}{l}-0.12^{* * *} \\
(5.4)\end{array}$ & & & & & $\begin{array}{l}-0.09^{*} \\
(1.6)\end{array}$ & \\
\hline NewDebt $(-1)$ & & & & & $\begin{array}{l}-0.4^{* * *} \\
(3.1)\end{array}$ & & & & & $\begin{array}{l}-0.2^{* *} \\
(2.5)\end{array}$ \\
\hline Estimator: & OLS & & & & & Marquar & LSS & & & \\
\hline $\begin{array}{l}\text { Adj. } R^{2} \\
\text { LM }\end{array}$ & 0.43 & 0.13 & 0.54 & 0.16 & 0.06 & 0.73 & 0.71 & 0.74 & 0.71 & 0.71 \\
\hline
\end{tabular}


In this way, we allow for feedback effects from output to borrowing as well as from borrowing to industrial output. Fig. 8 shows the impulse response of output to greater government borrowing. The effect is negative at the $95 \%$ level from year 2 and remains substantial and significant until year 5. A one standard deviation increase of government debt reduced output by a cumulative 5.2\% over 10 years, according to the VAR estimate. An international flow of capital to offset the scarcity of domestic credit as suggested by Neal cannot have had more than a limited effect, damping but not eliminating the consequences of domestic credit rationing.

We confirmed this result with a three-factor VAR (not reported), adding HGAP to the list of variables. As noted at the outset of this argument, Hoare's lending is a noisy proxy for total lending. The larger VAR confirms the result shown in Fig. 8 that industrial output responded negatively to government debt, although the standard errors are larger. Hoare's lending also declined in response to larger borrowing. Finally, Hoare's lending did not affect industrial production. This implies that, according to the VAR, changes to Hoare's lending that were orthogonal to government borrowing shocks did not exert an independent influence on output. The estimate is the converse of our IV estimates in Table 3, where we used only the part of Hoare's lending that was affected by government actions. The rest of Hoare's lending did not have any effect on industrial production; loans by Hoare's mattered so far as they were driven by government borrowing, but not in their own right. The bank was only a conduit for government policy, not an independent force affecting national income, as we would expect. This also suggests that, in the rest of our analysis, we are not capturing spurious correlations between Hoare's lending and the output series.

All the individual elements that are necessary to make the "crowding-out" story plausible are therefore in place - heavy government borrowing reduced private lending sharply, and industrial growth slowed markedly whenever public debt grew rapidly. This was especially true in years when the rise in public borrowing coincided with a private-sector credit crunch. We find that independent of the analytical technique used - from simply eyeballing the data to VAR analysis - quantity-based measures strongly suggest that "crowding out" in 18th-century Britain was substantial.

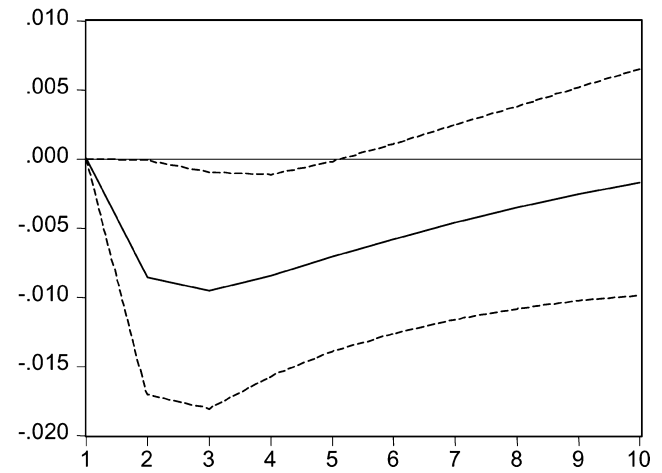

Fig. 8. Response of QGAP to Choletsky one SD innovation of DebtGAP. 


\section{Conclusions}

What is the connection between the financial revolution and the industrial revolution? We argue that earlier attempts to answer this question fell short because they focused on direct measures of the cost of credit intermediation. This procedure is flawed because interest rates were heavily regulated in 18th-century England, and there is ample reason to think that yields on government debt do not provide a meaningful guide to scarcity. Knowledgeable observers from Adam Smith to T.S. Ashton emphasized the importance of the usury laws in keeping interest rates low, independent of credit conditions, and the normal asymmetric information problems that dominate in many lending relationships.

We use micro-level evidence to argue that quantity rationing was indeed a key feature of England's credit market during the Industrial Revolution. Annual balance sheets from Hoare's Bank allow us to trace changes in the volume of lending over 160 years, from 1702 to 1862 . A number of findings stand out. Wartime borrowing did crowd out private lending on a massive scale. When war was imminent, Hoare's - anticipating that it would have to pay out deposits so that its customers could move funds into government securities - immediately started to boost its cash ratio. It did so by reducing credit to its customers, calling in old loans and refusing to make new ones. On balance, our results suggest substantial crowding-out, but perhaps on a scale of somewhat less than 1:1 (where a 1\% rise in government debt led to a $1 \%$ decline in Hoare's lending relative to their long-term trends). Instrumental-variable estimation suggests that wartime borrowing led to more severe crowding-out than normal government borrowing.

There is also ample evidence to suggest that the decline in lending volume slowed industrial growth, and hence hindered Britain's industrial transformation. Using the changes in lending volume at Hoare's as a proxy for total lending volume, we find that wartime contractions of output were particularly severe when accompanied by a private-sector "credit crunch." When the demands of Army and Royal Navy did not lead to tight credit conditions at home, however, growth was largely undisturbed. Our findings appear to suggest a comprehensive vindication of the crowding-out hypothesis. Once the right variables are analyzed, the impact of government borrowing is clear and strongly negative.

At the same time, our view into the lending process at an 18th-century goldsmith also cautions against such a one-sided conclusion. In examining the impact of wartime borrowing on private-sector lending volumes, we take the existence of a sophisticated system of deposit-taking banks for granted. Hoare's depositors left their money in their bank accounts in the expectation that, every few years, they could move their funds into safe government securities. It was war that provided this opportunity. Hoare's certainly considered the decline of deposits in wartime an integral part of its business, and it is an open question if its customers would have used its intermediation services to the same extent if the British government had not provided them with large volumes of liquid, trustworthy bonds. Without periodic bouts of fighting the French, Dutch, or Spanish, and the attendant funding requirements, the private banks - and not just the public securities markets emphasized by the lit- 
erature on the "financial revolution"-may have remained underdeveloped. The high elasticity of savings noted by many historians of 18th-century Britain suggests that private credit intermediation and government borrowing developed symbiotically, with growth of one fostering the development of the other. It is possible that the private sector could have developed alternative assets of similar appeal to consols, thus fostering the growth of an exclusively private system of credit intermediation. The history of other countries, however, does not suggest that this was a likely prospect. Hence, the negative impact of government borrowing that we document may have been largely short-term in nature. The positive institutional impulse of creating a pool of liquid, low-risk securities may have easily outweighed it in the long run.

Our results may also reconcile conflicting views of the Industrial Revolution. Using estimated quantities of inputs and outputs, Crafts and Harley have continued to emphasize slow growth and TFP growth. Factor prices analysed by Antràs and Voth support their conclusions (Antràs and Voth, 2003; Crafts and Harley, 1992). Slow growth appeared to imply limited changes in productive techniques. However, using trade statistics, Temin found evidence of widespread technical change in Britain between 1770 and 1830, with the implication that economic growth should have been faster (Crafts and Harley, 2000; Temin, 1997, 2000). If the Napoleonic Wars reduced the rate of income growth, this apparent paradox disappears. Had wars not interfered, British economic growth might have been more rapid in the late 18th and early 19th centuries as Temin's microeconomic evidence suggests it should have been. ${ }^{17}$ Instead of being on a balanced growth path, where rapid and widespread technological change should have led to faster growth and higher TFP, the British economy was hit by a sequence of negative, war-related shocks that reduced aggregate demand. Therefore, what slowed growth and depressed measured TFP was not slow technological change, but the pro-cyclical nature of productivity increases (Gordon, 1979). As Ashton put it (Ashton, 1968, pp. 103-104): "Government borrowing had another, no less important effect... Capital was deflected from private to public uses, and some of the developments of the industrial revolution were once more brought to a halt." Once the reservoir of technological advances could be tapped undisturbed - after the end of the Napoleonic Wars - growth accelerated, TFP growth increased, and real wages began to rise.

\section{References}

Acemoglu, D., Johnson, S., et al., 2001. The colonial origins of comparative development. American Economic Review 91 (5), 1369-1401.

Acemoglu, D., Johnson, S., et al., 2002. The rise of Europe: Atlantic trade, institutional changes and economic growth, NBER Working Paper w9378.

Antràs, P., Voth, H.-J., 2003. Productivity growth and factor prices during the British Industrial Revolution. Explorations in Economic History 40 (1), 52-77.

\footnotetext{
${ }^{17}$ Mokyr (1987) reached a similar conclusion by different means.
} 
Ashton, T.S., 1959. Economic Fluctuations in England, 1700-1800. Clarendon Press, Oxford.

Ashton, T.S., 1968. The Industrial Revolution, 1760-1830. Oxford UP, London, New York.

Brewer, J., 1989. The Sinews of Power: War, Money and the English State, 1688-1783. Alfred A. Knopf, New York.

Clark, G., 1996. The political foundations of modern economic growth: England, 1540-1800. Journal of Interdisciplinary History 26 (4), 563-588.

Clark, G., 2001. Debt, deficits, and crowding out: England, 1727-1840. European Review of Economic History 5 (3), 403-436.

Crafts, N.F.R., 1985. British Economic Growth during the Industrial Revolution. Oxford University Press, Oxford.

Crafts, N.F.R., Harley, C.K., 1992. Output growth and the british industrial revolution: a restatement of the Crafts-Harley view. Economic History Review 45 (4), 703-730.

Crafts, N.F.R., Harley, K., 2000. Simulating the two views of the industrial revolution. Journal of Economic History 60 (3), 819-842.

DeLong, J.B., Shleifer, A., 1993. Princes and merchants: city growth before the Industrial Revolution. Journal of Law and Economics 36 (2), 671-702.

Ferguson, N., 2001. The Cash Nexus: Money and Power in the Modern World, 1700-2000. Basic Books, New York.

Gordon, R.J., 1979. The "end-of-expansion" phenomenon in short-run productivity behavior. Brookings Papers on Economic Activity 2, 447-461.

Harley, C.K., 1999. Reassessing the Industrial Revolution: a macro view. In: Mokyr, J. (Ed.), The British Industrial Revolution: An Economic Perspective. Westview Press, Boulder, CA.

Heim, C.E., Mirowski, P., 1987. Interest rates and crowding-out during Britain's Industrial Revolution. Journal of Economic History 47 (1), 117-139.

Heim, C.E., Mirowski, P., 1991. Crowding out: response. [Interest rates and crowding-out during Britain's Industrial Revolution]. Journal of Economic History 51 (3), 701-706.

Hoffman, P.T., Postel-Vinay, G., et al., 2000. Priceless Markets: the Political Economy of Credit in Paris, 1660-1870. The University of Chicago Press, Chicago.

Jaffee, D., Stiglitz, J.E., 1990. Credit Rationing. In: Friedman, B.M., Hahn, F.H. (Eds.), Handbook of Monetary Economics, vol. 2. North-Holland, Amsterdam and New York, pp. 837-888.

Koenker, R., Hallock, K.F., 2001. Quantile regression. Journal of Economic Perspectives 15 (4), 143-156.

Levine, R., Zervos, S., 1998. Stock markets, banks, and economic growth. American Economic Review 88, $537-558$.

Mirowski, P., 1981. The rise (and retreat) of a market: English joint stock shares in the eighteenth century. Journal of Economic History 41 (3), 559-577.

Mitchell, B.R., 1971. Abstract of British Historical Statistics. Cambridge University Press, Cambridge.

Mokyr, Joel., 1987. Has the Industrial Revolution been crowded out? Some reflections on Crafts and Williamson. Explorations in Economic History 24 (3), 293-319.

Neal, L., 1990. The Rise of Financial Capitalism. Cambridge University Press, Cambridge.

North, D., Weingast, B., 1989. Constitutions and commitment: the evolution of institutions governing public choice in seventeenth-century England. Journal of Economic History 49 (4), 803-832.

Pressnell, L.S., 1956. Country Banking in the Industrial Revolution. Oxford.

Quinn, S., 1997. Goldsmith-banking: mutual acceptance and interbanker clearing in restoration London. Explorations in Economic History 34 (4), 411-432.

Quinn, S., 2001. The glorious revolution's effect on English private finance: a microhistory, 1680-1705. Journal of Economic History 61 (3), 593-615.

Rajan, R.G., Zingales, L., 1998. Financial dependence and growth. American Economic Review 88 (3), $559-586$.

Richards, R.D., 1929. The Early History of Banking in England. PS King \& Son, London.

Rousseau, P.L., Sylla, R., 2001. Financial Systems, Economic Growth, and Globalization, National Bureau of Economic Research Working Paper 8323: 31.

Smith, A., 1982 [1776]. An Enquiry into the Nature and Causes of the Wealth of Nations. London.

Stiglitz, J.E., Weiss, A., 1981. Credit rationing in markets with imperfect information. American Economic Review 71 (3), 393-410. 
Sussman, N., Yafeh, Y., 2002. Constitutions and commitment: evidence on the relation between institutions and the cost of capital." unpublished manuscript, Hebrew University, Jerusalem.

Temin, P., 1997. Two views of the British Industrial Revolution. Journal of Economic History 57 (1), $63-$ 82.

Temin, P., 2000. A response to Harley and Crafts. Journal of Economic History 60 (3), 842-846.

Temin, P., Voth, H.-J., 2003. Banking as an Emerging Technology: Hoare's Bank 1702-1742. MIT Economics Department working paper.

Temin, P., Voth, H.-J., 2004. Riding the South Sea Bubble. American Economic Review 93 (5), forth coming.

Williamson, J.G., 1984. "Why was British growth so slow during the Industrial Revolution?" Journal of Economic History 44 (3), 687-712.

Williamson, J.G., 1987. Has crowding out really been given a fair test? A comment [interest rates and crowding-out during Britain's Industrial Revolution]. Journal of Economic History 47 (1), 214-215. 